Biol. Stud. 2009: 3(1); 3-24 • DOI: https://doi.org/10.30970/sbi.0301.021

www.http://publications.Inu.edu.ua/journals/index.php/biology

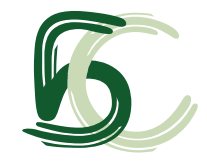

UDC 577.352.4:612.014.1

\title{
APPARENT DIFFUSION COEFFICIENT OF WATER IN EVALUATION OF TREATMENT RESPONSE IN ANIMAL BODY TUMORS
}

\author{
Andriy M. Babsky ${ }^{1,2}$, Shenghong Ju ${ }^{1,3}$, Navin Bansal ${ }^{1}$ \\ ${ }^{1}$ Department of Radiology, Indiana University \\ 950, West Walnut St., R2 E124, Indianapolis, IN 46202, USA \\ ${ }^{2}$ Ivan Franko National University of Lviv, 4, Hrushevskyi St., Lviv, 79005, Ukraine \\ ${ }^{3}$ Zhongda Hospital, Southeast University \\ 87, Dingjiaqiao Rd, Nanjing, 210009, China \\ e-mail: ababsky@iupui.edu
}

The review summarizes the author's results and literature data on the evaluation of diffusion-weighted magnetic resonance imaging (DWI) as a cancer biomarkers that reflects structural, cellular, apoptotic, and necrotic changes in tumor tissue. Diffusion measurements reflect the effective displacement of water molecules allowed to migrate for a given time. It was demonstrated that apparent diffusion coefficient (ADC) of water estimated from ${ }^{1} \mathrm{H}$ DWI is important tool for the detection and characterization of neoplastic transformation as well as monitoring response to therapy. The possible mechanisms of pre- and post-therapy changes in water ADC in animal body tumors are discussed.

Key words: tumor, chemotherapy, ADC, sodium, MRI.

Abbreviations: 5FU, 5-fluorouracil; ADC, apparent diffusion coefficient; BCNU, 1,3-bis(2-chloroethyl)-1-nitrosourea; Cp, cyclophosphamide; DWI, diffusion weighted imaging; ECS, extracellular space; ICS, intracellular space; MRI, magnetic resonance imaging; $\left[\mathrm{Na}^{+}\right]_{\mathrm{e}}$, extracellular $\mathrm{Na}^{+} ;\left[\mathrm{Na}^{+}\right]_{\mid,}$, intracellular $\left.\mathrm{Na}+; \mathrm{Na}^{+}\right]_{t}$, total tissue $\mathrm{Na}^{+} ; \mathrm{PET}$, positron-emission tomography; RIF-1, radiation induced fibrosarcoma-1; sc, subcutaneous; SI, signal intensity; SQ, single-quantum ${ }^{23} \mathrm{Na}$; TQF, triple quantum-filtered ${ }^{23} \mathrm{Na}$; TRAIL, tumor necrosis factor-related apoptosis-inducing ligand.

\section{INTRODUCTION}

The prediction and detection of the therapeutic response, as well as characterization of residual disease, are very important for effective cancer therapy. Current assessment of tumor treatment response relies on evaluating changes in the maximal crosssectional area or the diameter of the tumor [1, 2], weeks to months after the conclusion 
of a therapeutic protocol $[3,4]$. Several noninvasive imaging methods, such as computed tomography, positron-emission tomography, single-photon emission computerized tomography, magnetic resonance spectroscopy and diffusion-weighted magnetic resonance imaging (DW MRI or DWI) are being evaluated for assessing early therapeutic response that are independent of late changes in tumor volume [5-10].

The diffusion of tissue water in vivo can be accurately and noninvasively estimated as an apparent diffusion coefficient (ADC) by using ${ }^{1} \mathrm{H}$ DWI. It is a well known diagnostic tool to evaluate central nervous system pathologies. The first reported evaluation of mean tumor ADC following chemotherapy of an animal tumor model was performed by Ross et al. in 1994 [11], who studied effect of BCNU treatment on orthotopic rat 9L glioma. For many years the use of DWI was limited to the brain because the image quality of DWI of non-central nervous system tissue was inferior. Physiologic motion and the challenging magnetic environment outside the brain made it difficult to achieve DWI with sufficient image quality within a reasonable acquisition time. Within the last years advances in MRI software and hardware-sector of MRI improved image quality considerably and led to several reports describing the potential of DWI in the evaluation of extracranial diseases.

DW MRI has a number of advantages over other imaging techniques (e.g., computed (CT) and positron-emission tomographies (PET)). DW MRI is noninvasive, and does not require ionizing radiation exposure or the administration of contrast medium. The short examination time, especially when using parallel imaging, is an additional advantage, as is the ability to assess the tumor completely. In addition, parallel imaging offers the benefit of reduced artifacts, which becomes very important in DW MRI. Prediction of response to treatment or even early detection of non-responders would allow changes of therapy in order to minimize treatment-related toxicity. Furthermore, both conventional morphologic and physiologic assessments can be made during the same examination [12]. DWI provides both quantitative and qualitative information that can be useful for tumor treatment.

In preclinical models, there is abundant evidence that the ADC in tumors increases early in response to successful treatment. This has been shown in sarcoma, glioma, and breast carcinoma xenografts treated with cytotoxic chemotherapies, cytostatic chemotherapies, radiation therapy, and gene therapies [13, 14]. Treatments that caused cells to shrink led to early increases in ADC that were predictive of the ultimate tumor response. The observations have generated increasing interest in the clinical application of DW MRI for assessing tumor response during follow-up with various treatment modalities (e.g., chemotherapy and radiation therapy) [15-19].

Changes detected in mean tumor ADC values after treatment in rodent tumor models revealed that this approach has merit for preclinical drug development studies as a sensitive and early predictor of therapeutic efficacy [8, 14, 18, 20-24]. Furthermore, some preliminary studies have shown correlations between pre-treatment ADC value and tumor response to therapy. However, because of tumor heterogeneity and suboptimal methods of digital image analysis [15, 25-28], clinical utility of this approach is more complicated and therefore the application was delayed comparing with preclinical utility in rodent models. Many of the clinical studies evaluating DWI for assessing treatment response have been performed in relatively small numbers of patients. Nevertheless, the body of evidence suggests that ADC measurement is a potentially useful tool that provides unique prognostic information and should be more widely investigated in large clinical studies in the future [29].

The common points of view on ADC changes in tumor tissue are summarized in Fig. 1. Neoplastic transformation can lead to an increase in water ADC due to less 


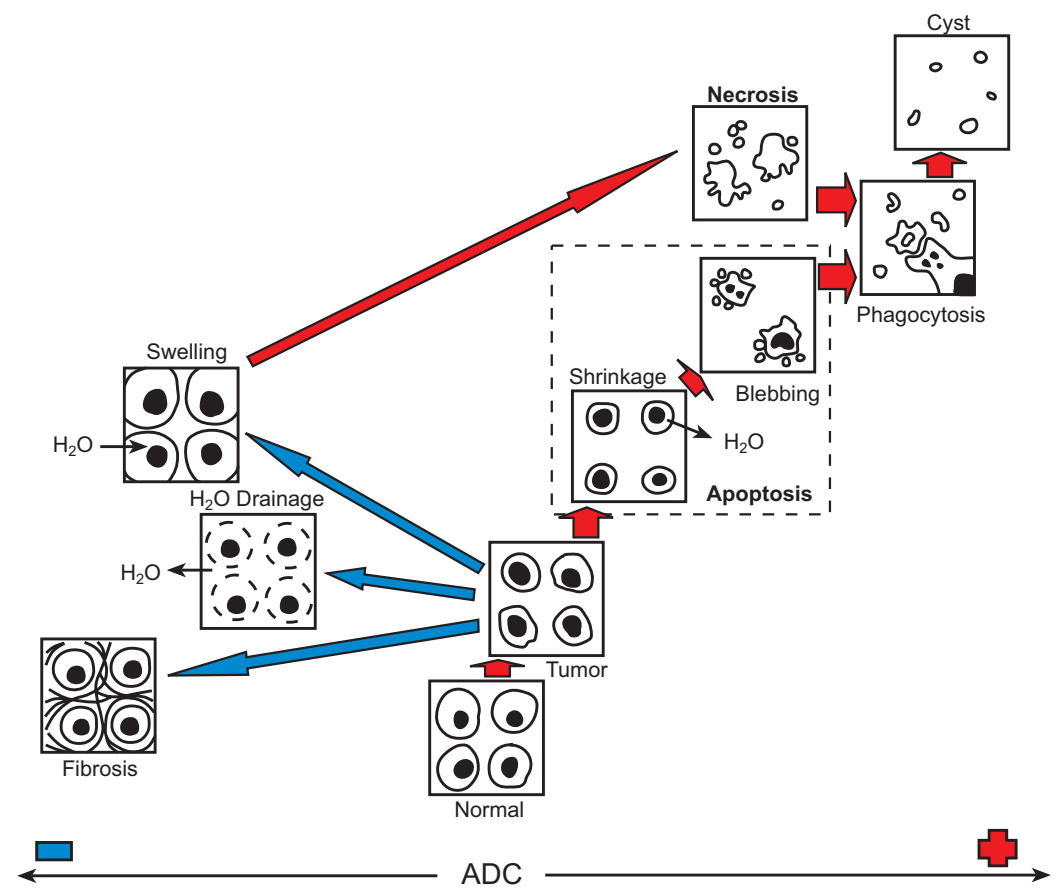

Fig. 1. Schematic diagram of possible mechanisms of the water apparent diffusion coefficient (ADC) increase (+) or decrease (-) in tumor tissue (Adapted from Moffat et al. [35] and Koh and Collins [29])

efficient cell packing in tumors compared to the healthy tissue. Ross et al. hypothesized that the changes in tumor ADC that occur after effective therapy can be related to changes in cell density [11,30-34] as result of necrotic and/or apoptotic processes. Both of these processes should lead to an increase in extracellular space (ECS) and an increase in water ADC. From other side, the loss of tumor membrane integrity causes water inflow, cell swelling, and a decrease in both ECS and water ADC especially in the beginning of the post-treatment period. Heterogeneous tumor tissues usually contain regions of intratumoral edema, necrosis, and cyst with high extracellular water content. Post-treatment dynamic reorganization of these regions involving tissue water drainage can also decrease water ADC. Furthermore, intensive fibrosis in tumor tissue can also contribute to restriction of water diffusion. Moffat et al. stated that „the changes in cell density due to cell killing along with tissue reorganization may lead to heterogeneous changes in the underlying tissue morphology (e.g., ratio of intra- to extracellular water), resulting in spatially varying changes in tumor ADC values" [35]. Koh and Collins consider that the explanation of ADC changes has to include not only the ECS changes but also the contribution of intravascular perfusion to the diffusion measurement, especially when the DWIs are acquired using low $b$-values, which are sensitive to vascular perfusion effects [29]. The diagram in Figure 1 also does not include the contribution of intracellular water ADC to total tissue value. The direct measurements of ADC of small molecules like sodium, gadolinium, mannitol, glucose and others show that intra- and extracellular ADCs are rather similar than different [36, 37]. The use of ADC to estimate chemotherapy efficiency has been assessed in a number of animal studies and summarized in Table and described below. 


\section{Variability in Animal Models and MRI Techniques in Water ADC Studies}

The extensive application of water ADC as a marker of the animal body tumor chemotherapy efficiency began about 13 years ago using mainly rats (Fisher, Wistar, Ludwig, etc.) and mice (C3H, BALB nude, SCID, GBNIH nude, etc.). For that purpose both clinical (1.5-4.7 T) and small animal (4.7-14 T) MRI systems were used. Different type of MR coils such as birdcage- [38, 39], loop-gap- [40-42], wrist- [43] and surface-coils [44] were used accordingly to the tumors location and volume. Majority of the experiments were performed using subcutaneous (sc) tumors. Sc tumor models are very convenient for NMR studies because they avoid the effects of motion present in the abdominal area and provide high quality MR images due to close location of the MR coil to the tumor tissue. The values of water ADC before treatment for many sarcomas [40, $42,45,46]$ and human breast cancer xenografts $[47,48]$ were reported in the range $0.4-0.7 \times 10^{-3} \mathrm{~mm}^{2} / \mathrm{s}$. However, Thoeny et al. $[43,49]$ show the higher water ADC value for rhabdomyosarcoma $\left(1.26 \times 10^{-3} \mathrm{~mm}^{2} / \mathrm{s}\right)$. Water ADC in sc gliomas (gliosarcomas) [38, $39,41]$ and mammary tumor xenografts [44] were found before treatment in the range $0.9-1.1 \times 10^{-3} \mathrm{~mm}^{2} / \mathrm{s}$. Pre-treated sc tumor volumes used for the water ADC estimation varied from $0.1-0.6 \mathrm{~cm}^{3}$ (mostly for carcinomas) to $1-2 \mathrm{~cm}^{3}$ (mostly for gliomas). Absolute ADC values, however, depend on the $b$-values applied for DW MRI. Unfortunately, the number of $b$-values in the different post-treatment studies of ADC varied very much - from two $\left(0\right.$ and $\left.300 \mathrm{~s} / \mathrm{mm}^{2}\right)[38,39,50]$ to fourteen $\left(15-2741 \mathrm{~s} / \mathrm{mm}^{2}\right)$ [51]. Only in few cases $b$-values higher than $1,000 \mathrm{~mm}^{2} / \mathrm{s}$ have been used [38-42, 51, 52]. Some investigators use $b$-value $=0 \mathrm{~s} / \mathrm{mm}^{2}[40-43,46,48]$, some of them do not [39, 44, 45, 47, 53]. These variations in $b$-values make the comparison of the ADC data complicated. As a quantitative parameter calculated from DWI, ADC reflects not only diffusion but also perfusion in microvessels [54]. Previous studies show that for low $b$-values $\left(<100 \mathrm{~s} / \mathrm{mm}^{2}\right)$ perfusion dominate diffusion by a factor of $10[54,55]$. However, by using high $b$-values $\left(>500 \mathrm{~s} / \mathrm{mm}^{2}\right)$, the influence of perfusion is largely attenuated. Thoeny et al. [43] divided $b$-values on low $\left(0,50\right.$, and $\left.100 \mathrm{~s} / \mathrm{mm}^{2}\right)$ and high $\left(500,750\right.$, and $\left.1,000 \mathrm{~s} / \mathrm{mm}^{2}\right)$. They propose to use the difference between $\mathrm{ADC}_{\text {low }}$ and $\mathrm{ADC}_{\text {high }}$ as a perfusion component of the tissue ADC. However, Zhao et al. [45] assume that the vascular contribution to tumor tissue water diffusion is minimal despite the greater water ADC in blood. This conclusion is based on the Braunschveiger study [56] showing that blood occupied less than $5 \%$ of sc RIF-1 volume. In addition, the effect of perfusion is diminished when wide ranges of $b$-values are used in a study. The challenges and recommendations concerning the application of DWI as a cancer biomarker are widely discussed in the recent review by Padhani et al. [57] published in Neoplasia.

In our paper, studies of water ADC in different animal body tumor models, such as a tumor of connective tissue, muscle, colon, breast, liver, prostate, and other tissues will be discussed.

\section{Fibrosarcomas and Myosarcomas}

The first report on the application of water ADC measurement for monitoring response to the body cancer therapy was published by Zhao et al. in 1996 [45]. This study was performed using a diffusion-weighted spectroscopy pulse sequence. The effects of cyclophosphamide (Cp), an alkyliting agent, on sc-implanted radiation induced fibrosarcoma-1 (RIF-1) in C3H mice were investigated using a $4.7 \mathrm{~T}$ MR system. Cp itself is a pro-drug, which is oxidized in the liver to 4-hydroxycyclophosphamide and subsequently

ISSN 1996-4536 • Біологічні Студії / Studia Biologica • 2009 • Том 3/№1 • С. 3-24 
converted to nitrogen mustard and other metabolites. In tumors, Cp metabolites do not directly disrupt cell metabolism, but rather these metabolites alkylate DNA and proteins. Water ADC of RIF-1 tumors increased at day 2, 3 and 4 after Cp treatment in the absence or before a decrease in tumor volume [45]. The magnitude and duration of the changes in ADC were dose dependent. A $300 \mathrm{mg} / \mathrm{kg}$ Cp dose caused a larger and more sustained increase in the ADC compared to a $150 \mathrm{mg} / \mathrm{kg}$ dose. Because water ADC was increased substantially at a time when there was no change in tumor volume for a dose which produces minimal cell kill, authors suggest that ADC measurement could provide a novel means for early detection of response to anti-cancer therapy.

More recently the increase in water ADC in sc-implanted RIF-1 tumors after chemotherapy with $\mathrm{Cp}$ and 5-fluorouracil (5-FU) has been confirmed using DW ${ }^{1} \mathrm{H}$ MRI $[40,42]$. A single injection of $\mathrm{Cp}(300 \mathrm{mg} / \mathrm{kg})$ or $5 \mathrm{FU}(25 \mathrm{mg} / \mathrm{kg})$ significantly increased the water ADC of RIF-1 tumors two and three days post-treatment while tumor volume was significantly decreased. Unlike $\mathrm{Cp}$, the action of $5 \mathrm{FU}$ involves its incorporation into RNA and metabolic activation to 5-fluoro-2'-deoxyuridine-5'-monophosphate, which inhibits thymidilate synthetase, a key enzyme in DNA synthesis and repair. In control (untreated) groups tumor ADC remained unchanged throughout the experiment. 5FU is most commonly used for treatment of breast and gastrointestinal cancer 5FU shows anti-hepatocellular carcinoma activity, both clinically [58, 59] and in animals [60]. Examples of water ADC images for a control and $\mathrm{Cp}$-treated tumor before and one, two, and three days after $\mathrm{Cp}$ injection are shown in Fig. 2. After $\mathrm{Cp}$ injection, water ADC increased progressively during the first three days post treatment. The water ADC increase was observed not only in the tumor regions with low cell density (bright region in the lower right quadrant of the tumor), but throughout the whole tumor. In the Cp group, the average water ADC increased from $0.49 \pm 0.02 \times 10^{-3} \mathrm{~mm}^{2} / \mathrm{s}$ (before treatment) to $0.58 \pm 0.03 \times 10^{-3} \mathrm{~mm}^{2} / \mathrm{s}$ (day $2, \mathrm{p}<0.05$ ) and

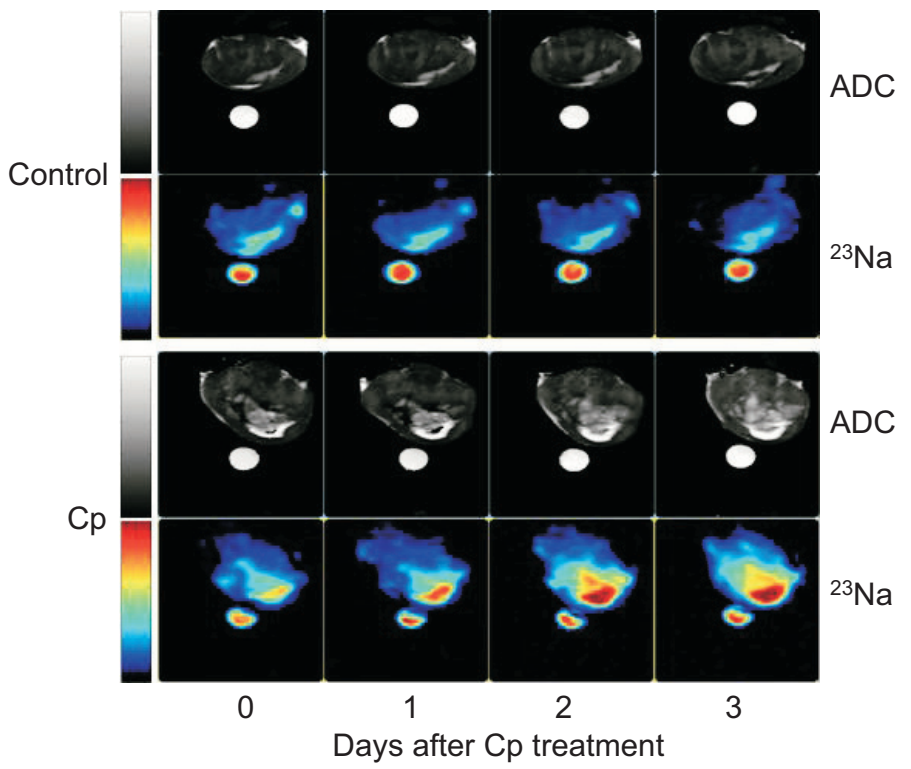

Fig. 2. Water apparent diffusion coefficient (ADC) maps and ${ }^{23} \mathrm{Na} M R$ images of representative control and cyclophosphamide $(\mathrm{Cp})$ treated RIF-1 tumors. Water ADC and ${ }^{23} \mathrm{Na}$ signal intensity increased with time after $\mathrm{Cp}$ treatment. A vial filled with a $\mathrm{NaCl}$ solution was placed near the tumor as a reference 
$0.73 \pm 0.04 \times 10^{-3} \mathrm{~mm}^{2} / \mathrm{s}$ (day $3, \mathrm{p}<0.01$ ). In $5 \mathrm{FU}$ group, the average water ADC increased from $0.52 \pm 0.02 \times 10^{-3} \mathrm{~mm}^{2} / \mathrm{s}$ (before treatment) to $0.61 \pm 0.02 \times 10^{-3} \mathrm{~mm}^{2} / \mathrm{s}$ (day $2, \mathrm{p}<0.05$ ) and $0.65 \pm 0.03 \times 10^{-3} \mathrm{~mm}^{2} / \mathrm{s}$ (day $3, \mathrm{p}<0.05$ ). The average water ADC of treated tumors was also significantly higher $(p<0.01)$ compared to the unchanged ADC of untreated control tumors two and three days post-treatment.

Braunschweiger [56] has shown that $\mathrm{Cp}$ treatment reduces cell proliferation and increases extracellular, interstitial and plasma water volumes during the initial five days after the treatment. The increase in extracellular water, cell death, and/or reduction in cell volume may increase the overall mobility of water in the damaged tissue and lead to an increase in water ADC. Destructive chemical analysis and histological results of RIF-1 tumors support this hypothesis. Measurment of relative ECS by destructive chemical analysis show $46 \pm 8 \%$ ECS in treated tumors compared to $26 \pm 4 \%$ in untreated tumors. Similarly, histological data shows a decrease in the number of cells and an increase in extracellular space $[40,42]$. It has been shown previously that the increase in water ADC correlates with both the increase in tumor necrotic fraction in RIF1 tumors [61] and with the decrease in tumor cell density in 9L glioma [62]. 5FU-treatment of RIF-1 tumors also led to increase in ECS. The ratio of necrotic to total tumor area in histological sections was $52 \%$ higher than to controls three days after the treatment. Furthermore, cellular density was $26 \%$ lower in necrotic areas of the treated tumors [42]. In necrotic areas of tumors, much evidence of apoptotic and necrotic change was found, such as dusting nuclei, pyknosis, neutrophil invasion, and/or karyorrhexis.

Thoeny et al. used a rhabdomyosarcoma tumor model to study the effects of the vascular targeting agent combretastatin A4 on water ADC using a $1.5 \mathrm{~T}$ MR system [19, $43,49]$. Combretastatin A4 produces a reversible disruption of the vascular network in tumors causing cell death without damaging the vasculature of normal organs [63]. The authors proposed that the difference between the ADC values calculated using low $b$ values of 0,50 , and $100 \mathrm{~s} / \mathrm{mm}^{2}\left(A C_{\text {low }}\right)$ and high $b$-values of 500,750 , and $1,000 \mathrm{~s} / \mathrm{mm}^{2}$ $\left(A D C_{\text {high }}\right)$ provides information about the perfusion component in ADC (ADC $\left.{ }_{\text {perf }}\right)$ [49]. They showed that treatment of sc-implanted rhabdomyosarcoma with a single ip dose of $25 \mathrm{mg} / \mathrm{kg}$ combretastatin A4 leads to significant decreases in $\mathrm{ADC}_{\text {low }}, \mathrm{ADC}_{\text {high}}$, and $\mathrm{ADC}_{\text {perf }} 1$ and $6 \mathrm{hr}$ post-treatment and is associated with tumor growth delay. However, two and nine days after combrestatin A4 injection when the tumor growth delay turned up to significant growth, $A D C_{\text {low }}$ and $A D C_{\text {high }}$ started to increase overlapping the before treatment values. $A D C_{\text {perf }}$ was still lower on day 2 but increased on day 9 compared to the before treatment value. The changes in $A D C_{\text {perf }}$ were correlated with the volume transfer constant $k\left(R^{2}=0.46\right)$ and the initial slope $\left(R^{2}=0.67\right)$ calculated from perfusion data using dynamic contrast-enhanced MRI. The changes of mean ADC from the entire rhabdomyosarcoma showed similar trend to the $\mathrm{ADC}_{\text {high }}$ changes [19]. Thus, total tumor ADC showed an early decrease after combretastatin A4 injection from $1.26 \times 10^{-3} \mathrm{~mm}^{2} / \mathrm{s}$ (before) to $1.18 \times 10^{-3} \mathrm{~mm}^{2} / \mathrm{s}(1 \mathrm{hr})$ and $1.08 \times 10^{-3} \mathrm{~mm}^{2} / \mathrm{s}(6 \mathrm{hr})$, histologically corresponding to vessel congestion and vascular shutdown in periphery but no necrosis. An increase of total tumor ADC $\left(1.79 \times 10^{-3} \mathrm{~mm}^{2} / \mathrm{s}\right) 2$ days after the drug injection was associated with progressive necrosis and a significant decrease 9 days after treatment $\left(1.41 \times 10^{-3} \mathrm{~mm}^{2} / \mathrm{s}\right)$ corresponded to tumor re-growth. Repeated combretastatin A4 administration at a dose of $25 \mathrm{mg} / \mathrm{kg}$ injected with an interval period of nine days retains efficacy in rat rhabdomyosarcomas, with similar effects on water ADC after each drug administration [43]. The authors concluded that both DW and dynamic contrast-enhanced MRIs provide information about intratumoral cell viability and necrosis and allow monitoring of perfusion changes after administration of vascular targeting agents.

ISSN 1996-4536 • Біологічні Студії / Studia Biologica • 2009 • Том 3/№1 • С. 3-24 


\section{Colon Tumor}

The earliest significant response of water ADC to chemotherapy was reported for the treatment of the sc-implanted human colon H29 carcinoma xenografts in GBNIH nude mice with inhibition of HIF- $\alpha$ by PX-478 [53]. PX-478 is a novel agent that suppresses both constitutive and hypoxia-induced levels of HIF- $\alpha$ in cancer cells [64]. PX-478-induced inhibition of tumor growth is associated with $\mathrm{HIF}_{-1} \alpha$ levels in different human tumor xenografts. At 24 and $36 \mathrm{hrs}$ after the treatment with this drug water ADC increased by $94.5 \%$ and $38.4 \%$ ( $p<0.01$ ), respectively, before returning to the pretreatment ADC level. However, PX-278 had no effect on the ADC of a drug-resistant tumor system.

Roth et al. treated sc-implanted C26 colon carcinomas with doxorubicin and with aminolevulenic acid-based photodynamic therapy (PDT) [51]. In malignant cells, doxorubicin-induced intercalation inhibits nucleotide replication and action of DNA and RNA polymerases. The interaction of doxorubicin with topoisomerase II to form DNA-cleavable complexes appears to be an important mechanism of doxorubicin cytocidal activity. The photodynamic therapy is a regional therapy that induces early destruction of tissue, whereas the effect of doxorubicin chemotherapy is systemic and seen much later. To quantify the diffusion characteristics of the tumor tissue, the authors defined a diffusion index, $R_{\mathrm{D}}$. They stated that $\Delta R_{\mathrm{D}}$ reflect changes in tumor viability, intracellular water fraction, and integrity of cell membranes that may affect permeability. In doxorubicin-treated carcinomas, a significant correlation was found between $R_{\mathrm{D}}$ measured prior to treatment, and changes in tumor volume after therapy. An average negative change in tumor $R_{\mathrm{D}}$ was observed after chemotherapy $\left(\Delta R_{\mathrm{D}}=-3.1 \pm 0.5\right)$ and PDT $\left(\Delta R_{\mathrm{D}}=-4.4 \pm 1.0\right) 24$ or $48 \mathrm{hr}$ post-treatment. In general, a negative change in $R_{\mathrm{D}}$ corresponds to an increase in water ADC. No substantial changes in diffusion were observed in control tumors. Tumors with high pretreatment viability responded better to chemotherapy with doxorubicin than more necrotic tumors. In tumors treated with photodynamic therapy, no such correlation was detected. Changes observed in water diffusion 24-48 hrs after treatment correlated with later carcinoma growth rate for both therapies.

The most durable increase in water ADC was reported by Seierstad et al. [46] when sc-implanted human HT29 colon adenocarcinoma xenografts were treated weekly with the 5FU prodrug capecitabine, daily oxaliplatin, and fractional irradiation. Oxaliplatin is a platinum-based chemotherapy drug in the same family as cisplatin and carboplatin. It is typically administered in combination with fluorouracil and leucovorin in a combination known as FOLFOX for the treatment of colorectal cancer. Compared to cisplatin the two amine groups are replaced by cyclohexyldiamine for improved antitumor activity. The chlorine ligands are replaced by the oxalato bidentate derived from oxalic acid in order to improve water solubility. Seierstad et al. found an increase in water ADC by $19 \%$ with combinations of the capecitabine and oxaliplatin on 11 days after the drug applications [46]. The combination of these drugs with fractionated irradiation showed a significant increase in tumor doubling growth delay compared to the tumors that received radiation only. Histological examination showed that both treated and control tumors had necrotic centers, ranging from 12 to $84 \%$, and that there was a much higher ADC value compared to the surrounding viable regions. However, the statistical analysis revealed no differences in necrotic fraction between the six treatment groups including control one. The same authors have studied the effect of $15 \mathrm{~Gy}$ irradiation alone on the same tumor model, and have found that $24 \mathrm{hr}$ post-radiation the water ADC was increase by $5.0 \%(p<0.002)[50]$. This increase was followed by a significant decrease $(-6.9 \%$, 
$p<0.001)$ three days post-radiation and a renewed increase of the water ADC on day $7(+6.2 \%, p<0.03)$ and $11(+11.1 \%, p<0.001)$. The decrease in water ADC three days post-radiation was accompanied with increased fibrosis in the treated tumors.

\section{Breast Tumor}

Galons et al. monitored the chemotherapy response of human breast MCF-7 cancer tumor xenografts to paclitaxel (27 mg/kg after the first MRI experiment and $18 \mathrm{mg} / \mathrm{kg}$ every other day) was monitored [47]. Paclitaxel binds to the $\beta$ subunit of tubulin interfering with normal microtubule breakdown during cell division. This drug is related to taxanes, which also induce apoptosis in cancer cells by binding to an apoptosis stopping protein called $\mathrm{Bcl}-2$ and thus arresting its function. Water ADC increased from $0.5-$ $0.7 \times 10^{-3}$ to $0.7-1.5 \times 10^{-3} \mathrm{~mm}^{2} / \mathrm{s} 48 \mathrm{hr}$ after successful therapy in parental drug-sensitive MCF-7/S tumors, but there was no change in the water ADC in p-glycoprotein-positive tumors MCF-7/D40, which are resistant to paclitaxel. The authors concluded that the mechanism underlying these changes is consistent with apoptotic cell shrinkage and a concomitant increase in the extracellular water fraction.

Chinnayan et al. monitored the human breast MCF-7 cancer xenografts therapy with tumor necrosis factor-related apoptosis-inducing ligand (TRAIL) [65]. TRAIL is a ligand molecule which induces caspase-8-dependent apoptosis. It is a type II transmembrane protein with homologous to other members of the tumor necrosis factor family that can binds to the death receptors, DR4 and DR5. The authors have found an increase in water ADC from $0.7 \times 10^{-3} \mathrm{~mm}^{2} / \mathrm{s}$ to $1.7 \times 10^{-3} \mathrm{~mm}^{2} / \mathrm{s}$ in combined TRAIL- and radiationtreated tumors seven days post-treatment but not in tumors treated with these therapies separately. Histological analysis confirmed a decrease in cellularity and activation of apoptotic activity in tumor cells after the TRAIL and radiation therapy.

Morse et al. treated the human breast MCF-7 and MDA-mb-231 cancer xenografts with the chemotherapeutic agents docetaxel (15 and $30 \mathrm{mg} / \mathrm{kg}$ ). The main mode of therapeutic action of docetaxel is the suppression of microtubule dynamic assembly and disassembly, rather than microtubule bundling leading to apoptosis, or the blocking of Bcl-2 [66] Docetaxel has greater cytotoxicity than paclitaxel, possibly due to its more rapid intracellular uptake. MCF-7 cells are partially deficient for apoptosis, and MDAmb-231 cells are not. The authors examined whether MRI-measured ADC is altered in response to therapies that induce cell death via non-apoptotic mechanisms and correlates ADC changes with cell death modalities regionally within the tumor. There was a post-treatment increase in tumor ADC that was generally associated with the central region of the tumor, which had low cellularity as determined by histology. The water ADC values from multiple slices in both MCF-7 and MDA-mb-231 tumors show an increase from about $0.5 \times 10^{-3} \mathrm{~mm}^{2} / \mathrm{s}$ to values approaching $1.0-1.5 \times 10^{-3} \mathrm{~mm}^{2} / \mathrm{s}$ two to four days post-treatment. The authors observed a general trend towards increasing water ADC with increasing dose. Both tumors showed a decrease in the number of pixels after treatment relative to carrier-treated controls, implying tumor shrinkage. These results indicated that early and significant changes in ADC can be related to mitotic catastrophe and lytic necrosis in the absence of apoptosis. The authors proposed to use changes in ADC as a generalized measure of cytotoxic reaction to chemotherapy.

Lemaire et al. examined the effect of $5 F U(100 \mathrm{mg} / \mathrm{kg}$, ip) on the water ADC in a rat mammary tumor induced by $\mathrm{N}$-methyl-N-nitrosurea [44]. They showed that the 5FUtreated tumors were not distinguishable in terms of tumor volume change up to day 5 ,

ISSN 1996-4536 • Біологічні Студії / Studia Biologica • 2009 • Том 3/№1 • С. 3-24 
whereas the water ADC over the same period of time did distinguish the sensitive and non-sensitive groups. They found that mammary tumors with low initial ADC values responded to a single 5FU bolus therapy by a $30 \%$ increase in ADC at day 7 after treatment, whereas tumors with high initial ADC showed a $30 \%$ decrease and tumors with intermediate values showed no significant change in ADC.

\section{Subcutaneous Brain Tumor}

Post-treatment changes in water ADC in rat intracranial glioma have been well described [62, 67-70]. In some studies 9L glioma was inoculated subcutaneously and thus it can be classified as a body gliosarcoma. The effects of alkylating agent 1,3-bis(2-chloroethyl)1-nitrosourea (BCNU) on Sc model of $9 \mathrm{~L}$ glioma have been studied [38, 39, 41, 71]. BCNU or carmustine is a mustard gas-related $\alpha$-chloro-nitrosourea compound used as an alkylating agent that attacks the 0-6 group of guanine in DNA. It is a lipid-soluble drug that can penetrate into the central nervous system. BCNU is used in the treatment of several types of brain cancer (including glioma, glioblastoma multiforme, medulloblastoma, and astrocytoma), multiple myeloma and lymphoma (Hodgkin's and non-Hodgkin).

Babsky et al. have shown that in sc-implanted 9L glioma, water ADC increased with growth in sham-treated control as well as non-responsive tumors $\left(\mathrm{NR}_{\mathrm{BCNU}}\right)$ after $\mathrm{BCNU}$ treatment [41]. The water ADC did not change significantly after effective treatment with $B C N U\left(R_{B C N U}\right)$ when the tumor growth was arrested (Fig. 3). The increase in water ADC with tumor growth may be due to an increase in ECS that may result from inefficient cell packing and aberrant and leaky vasculature with tumor growth. However, a previous study showed that the relative extracellular spaces, which were measured by destructive chemical analysis, in untreated control and BCNU-treated tumors are identical [71]. Several researchers have shown decreases in tumor $A T P / P_{i}$ and $P C r / P_{i}$ ratios with untreated growth [71-73]. This decrease in ATP level should decrease the activity of the $\mathrm{Na}^{+} / \mathrm{K}^{+}$-ATPase. On the other hand, $\mathrm{Na}^{+} / \mathrm{H}^{+}$exchanger activity may increase because of increased glycolytic rates and intracellular acid production in poorly perfused and hypoxic tumor tissue. These two effects should increase $\left[\mathrm{Na}^{+}\right]_{i}$ with untreated growth. The de-

Fig. 3. Effect of 1,3-bis(2-chloroethyl)-1-nitrosourea (BCNU) therapy on water apparent diffusion coefficient (ADC) in subcutaneously (sc) implanted 9L glioma. Control - non-treated animals, $\mathrm{NR}_{\mathrm{BCNU}}-\mathrm{BCNU}$ non-responsive, $\mathrm{R}_{\mathrm{BCNU}}-\mathrm{BCNU}$ responsive. Significance: $p \leq 0.05^{*}$ (vs. before treatment), ${ }^{* *}$ (vs. Control), ${ }^{* * * *}\left(\mathrm{R}_{\mathrm{BCNU}}\right.$ vs. $\left.\mathrm{NR}_{\mathrm{BCNU}}\right)$

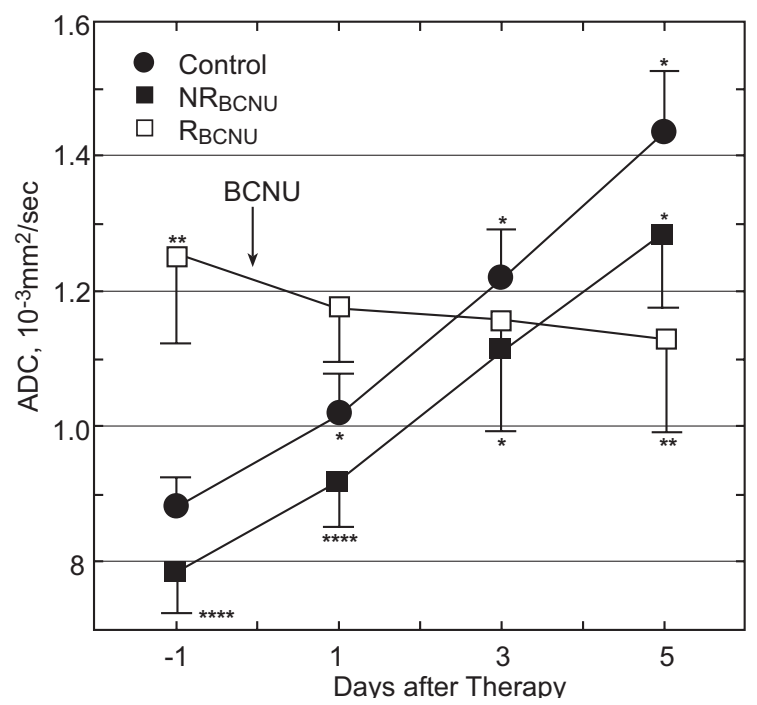


cline in cellular energetics and the increase in $\left[\mathrm{Na}^{+}\right]_{i}$ could also result in altered watermacromolecular interactions and changes in cytoplasmic viscosity due to cell swelling. These changes could alter water ADC in the intracellular compartment as well. Another reason for an increase in water $A D C$ in untreated $\mathrm{sc}$ glioma could be increased necrosis and cyst [74]. Lemaire et al. [44] showed that the water ADC of necrotic tissue is between two- and three-fold higher than for non-necrotic tumor tissue. The observed increases in water ADC with growth of sc-implanted 9L glioma and interruption of these changes with BCNU therapy are in contrast to previous results reported for intracranial 9L glioma [52] and sc-implanted tumors (presented in Table), which show increases in water ADC after therapy. However, Dzik-Jurasz et al. [75] reported a decrease in water ADC for some patients with rectal adenocarcinoma after neoadjuvant chemoradiation, and Mardor et al. [76] showed that changes in water ADC varied from patient to patient after chemotherapy of human glioma. Moffat et al. [35] have analyzed the sensitivity/ resistance of human brain tumors to treatment by evaluating the changes or lack thereof in water ADC. The authors associated an increase in water ADC after treatment with cell lysis, apoptosis, necrosis involving cell shrinkage, and blebbing followed by phagocytosis. A decrease in tumor water ADC they explained by 1) cell enlargement associated with mitotic catastrophe, 2) a reduction in tumor blood flow resulting in focal ischemia/hypoxia, and 3) by drainage of tumor water (Fig. 1). The authors concluded that a significant increase or decrease in tumor ADC values occurring after treatment indicates likelihood some response to therapy, but a lack of change in tumor ADC values indicates a therapeutically unresponsive tumor. However, these observations were made on the basis of clinical observations during weeks and months after different treatments. All these data show that changes in water ADC following therapy can be different in different tumors, or even in the same tumor cell line at different locations, e.g., intracranial versus sc-implanted glioma. A proper characterization and understanding of the changes in water ADC and ${ }^{23} \mathrm{Na} \mathrm{MRI} S \mathrm{SI}$ in the same tumors at different locations is very important for application of these techniques for monitoring therapy in orthotopic tumors.

\section{Liver, Prostate, and Other Tumors}

The effects of chemotherapy in animal liver tumors have been studied using orthotopic tumors. Transcatheter hepatic arterial chemoembolization is a classic interventional therapy for hepatocellular carcinoma and secondary liver cancers. In chemoembolization, the blood supply to the tumor is blocked surgically or mechanically and anticancer drugs are administered directly into the tumor. This permits a higher concentration of drug to be in contact with the tumor for a longer period time. Geschwind et al. used transcatheter hepatic arterial chemoembolization with carboplatin to treat VX2 tumor in the rabbit liver [13]. Carboplatin is a platinum-based chemotherapy drug used to treat various types of cancers, including sarcomas, lymphomas, and germ cell tumors. Platinum complexes are formed in cells, which bind and cause cross-linking of DNA ultimately triggering apoptosis. The water ADC in the rabbit VX2 liver carcinomas tumor was evaluated after sacrificing of the animals to prevent motion artifacts. DWI delineated regions of tumor cell death as zones of lower signal intensity (SI) in both control and treated groups. Water ADC was significantly greater in the area of tumor necrosis compared to the area of viable tumor cells. Histological analysis showed a significantly lower amount of viable cells after treatment $(<1 \%)$ compared to the untreated control group (55\%). Bsl-2 was expressed in the liver tumor after chemoembolization, suggesting an apoptotic pathway of cell death.

ISSN 1996-4536 • Біологічні Студії / Studia Biologica • 2009 • Том 3/№1 • С. 3-24 
Yuan et al. used another type of chemoembolization of the rabbit VX2 tumor in the liver when iodized oil $(0.3 \mathrm{~mL} / \mathrm{kg})$ and pharmorubicin $(2 \mathrm{mg} / \mathrm{kg})$ were infused into the hepatic artery [77, 78]. Similar to doxorubicin pharmorubicin is an anthracycline antibiotic that interacts with DNA by intercalation and inhibition of macromolecular biosynthesis [79]. This inhibits the progression of the enzyme topoisomerase II, which unwinds DNA for transcription. The authors anesthetized rabbits with $3 \%$ soluble pentobarbitone into auriborder vein to slow and stabilize animal breathing. Using $b$-values of $100 \mathrm{~s} / \mathrm{mm}^{2}$ and $300 \mathrm{~s} / \mathrm{mm}^{2}$, water ADC in surrounding liver tissue $\left(2.71 \times 10^{-3} \mathrm{~mm}^{2} / \mathrm{s}\right.$ and $2.30 \times 10^{-3} \mathrm{~mm}^{2} / \mathrm{s}$, respectively) tissue was higher than in the tumor center $\left(1.77 \times 10^{-3} \mathrm{~mm}^{2} / \mathrm{s}\right.$ and $1.55 \times 10^{-3} \mathrm{~mm}^{2} / \mathrm{s}$, respectively). They have found that under both $b$-values $100 \mathrm{~s} / \mathrm{mm}^{2}$ and $300 \mathrm{~s} / \mathrm{mm}^{2}$ the water ADC decreased in the tumor periphery 6 and $16 \mathrm{hr}$ post-treatment while at 32 and $48 \mathrm{hr}$ post-treatment it started to increase. A similar trend was found for water ADC changes in normal liver parenchyma area around the tumor. The authors concluded that necrotic liver tumors manifests low signal and high ADC value, while viable tumor manifests high ${ }^{1} \mathrm{H}$ signal and low ADC value after chemoembolization.

An orthotopic pancreatic tumor model was used to study the early therapeutic efficacy of monometric monoclonal anti-death receptor 5 antibody (TRA-8) combined with gemcitabine using DW ${ }^{1} \mathrm{H}$ MRI [80]. An anti-death receptor 5 is predominantly expressed in most cancer cells but not in normal cells. TRA-8 was developed specifically to target this receptor. As with fluorouracil and other analogues of pyrimidines, gemcitabine replaces cytidine of nucleic acids, during DNA replication, arresting tumor growth, as new nucleosides cannot be attached to the "faulty" nucleoside, resulting in apoptosis. To prevent the transfer of the respiratory motion in the chest and abdominal area, an orthogonally bent plastic board was used. At day 1 after the beginning of the combined TRA-8 and gemcitabine therapy water ADC in tumor regions was $27 \%$ higher than in untreated controls or those treated with gemcitabine only. At that time point no statistical difference in tumor volume was found. The mean water ADC values gradually increased over three days, which were concurrent with tumor volume regression. An increase in ADC was correlated with an increase in apoptotic cells density of tumors and with mean survival times of animals treated with the same drugs.

Jennings et al. studied the effect of docetaxel $(10,30$, and $60 \mathrm{mg} / \mathrm{kg})$ on water ADC in prostate cancer xenografts Sc-implanted into the flanks of SCID mice, which are severely deficient in $T$ and $B$ cells and fail to reject allogenic grafts or produce antibodies to common antigens [81]. They showed that tumor volumes and secreted prostatespecific antigen both vary inversely with docetaxel dose, and that the water ADC increased significantly by day 2 and day 4 post-treatment with all drug doses. Authors concluded that DW MRI can be used for early detection of prostate carcinoma xenograft response to docetaxel chemotherapy, and water ADC changes may be used to optimize timing of fractioned chemotherapy such that effective doses may be applied when the tumor shows its highest ADC related to the high tumor vulnerability.

Vogel-Claussen et al. used the vascular-targeting agent ZD6126 to treat Sc DU-145 human prostate cancer xenografts in SCID mice [82]. ZD6126 is a prodrug for N-acetycholinol (NAC), a tubulin-binding agent that inhibits tubulin polymerization and leads to microtubule destabilization selectively in the immature endothelial cells of the tumor neovasculature [83]. After iv administration ZD6126 rapidly converts to NAC. In non-resistant to the drug tumors, the treatment caused progressive cell necrosis in the central tumor region within $24 \mathrm{hr}$ post-treatment that was associated with a trend towards restricted diffusion. The authors explained this effect as a result of acute tumor ischemia, followed by 


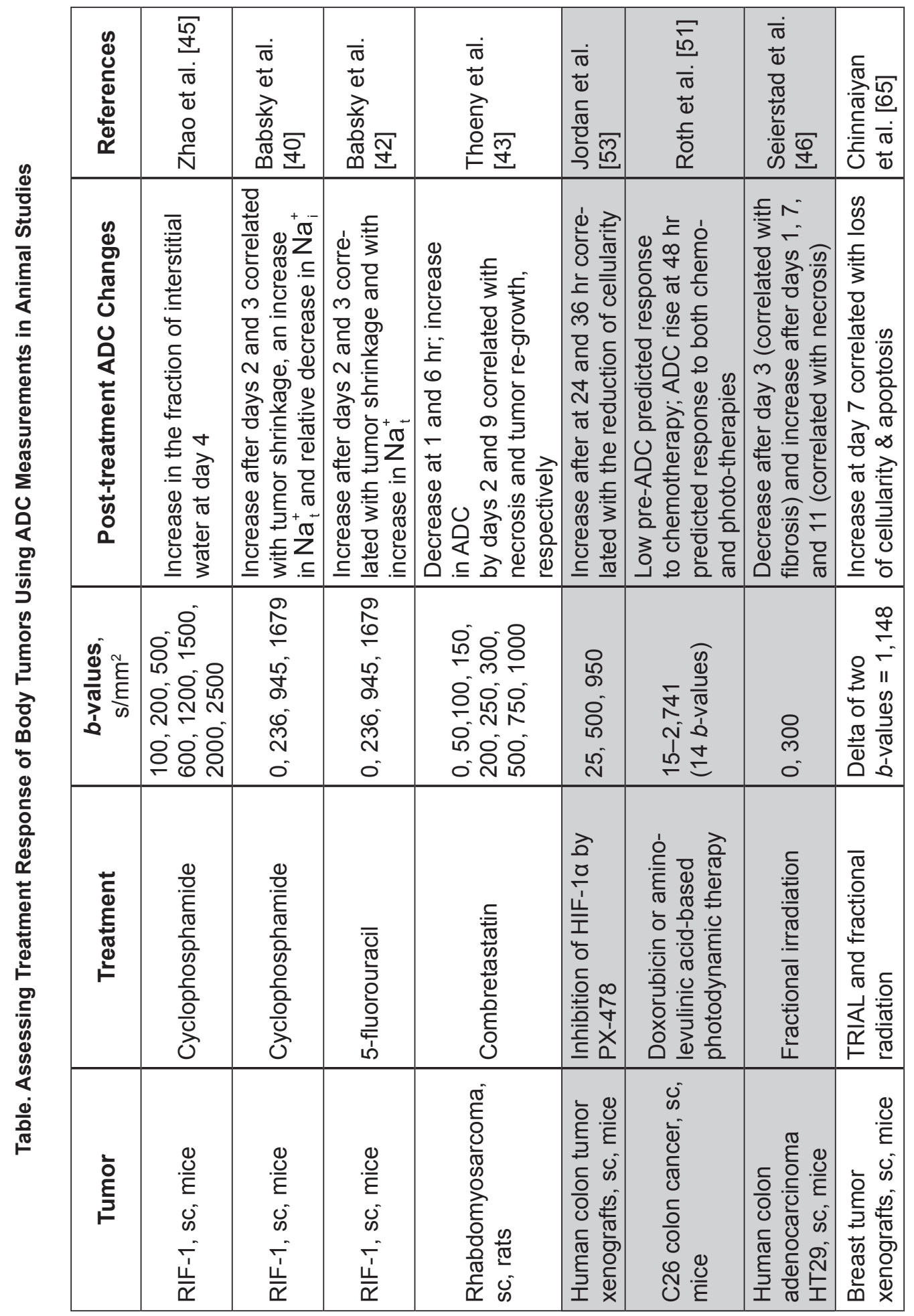




\begin{tabular}{|c|c|c|c|c|c|c|c|c|c|}
\hline 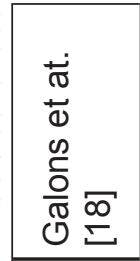 & 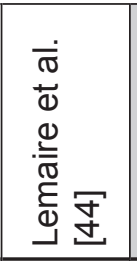 & 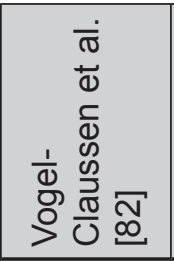 & 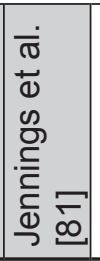 & 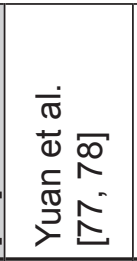 & 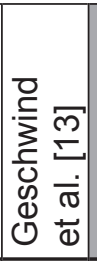 & 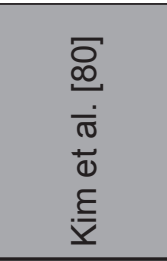 & 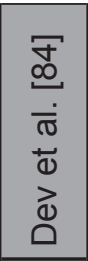 & 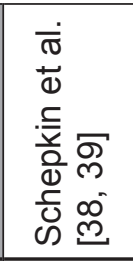 & 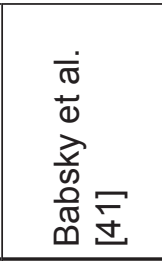 \\
\hline 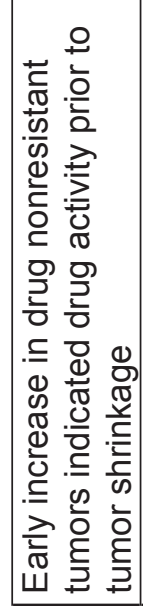 & 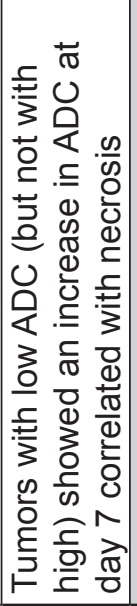 & 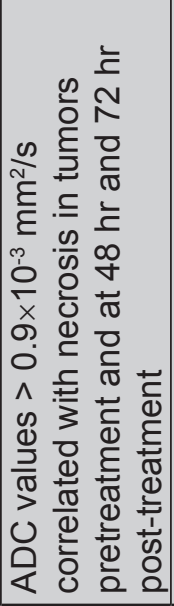 & 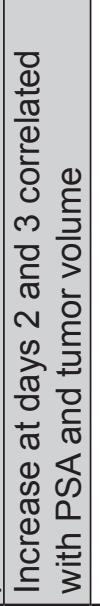 & 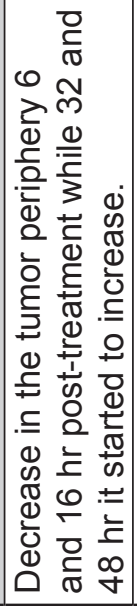 & 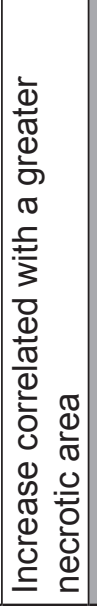 & 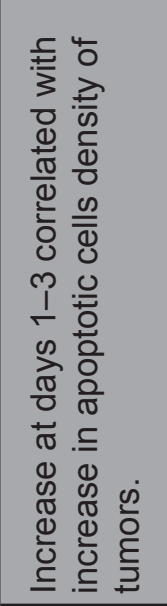 & 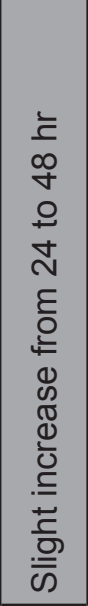 & 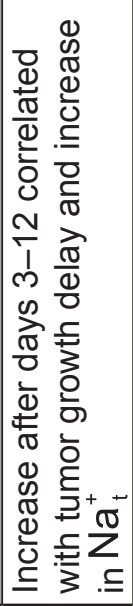 & 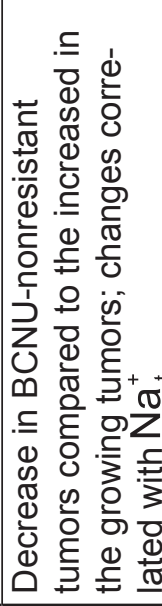 \\
\hline 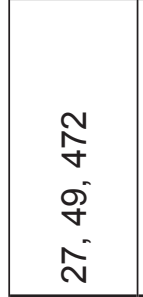 & 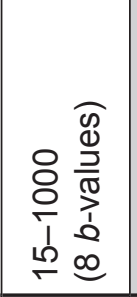 & $\begin{array}{l}0 \\
8 \\
0 \\
0 \\
8 \\
8 \\
0 \\
8 \\
\text { N } \\
0 \\
0\end{array}$ & 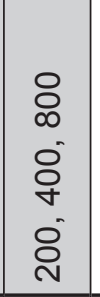 & $\begin{array}{l}\text { ㅇ } \\
\text { ల } \\
\text { ᄋ́ } \\
\text { ᄋ }\end{array}$ & $\frac{\nwarrow}{z}$ & $\frac{\pi}{z}$ & $\frac{\nwarrow}{z}$ & 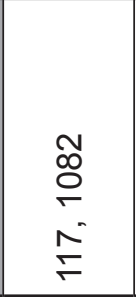 & 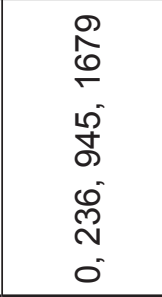 \\
\hline 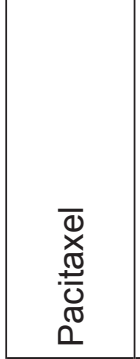 & 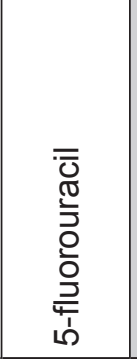 & 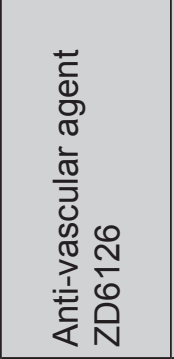 & 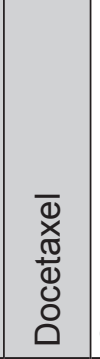 & 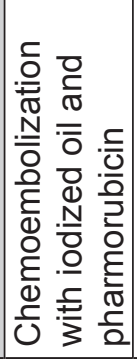 & 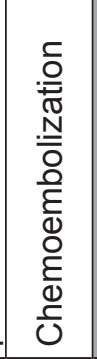 & 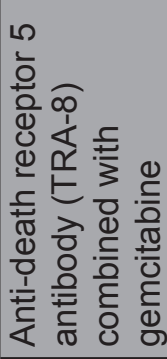 & 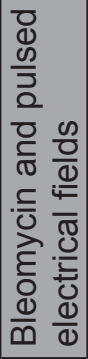 & 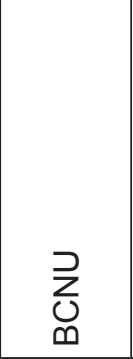 & 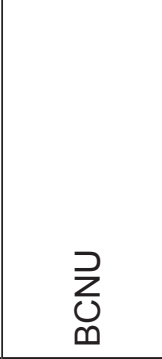 \\
\hline 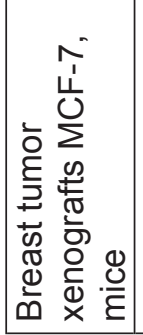 & 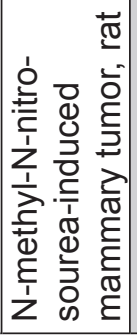 & 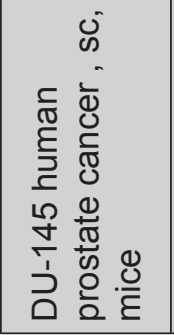 & 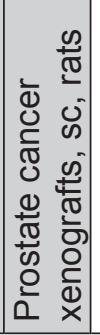 & 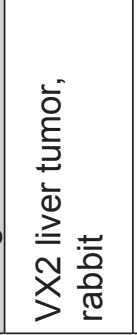 & 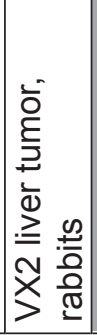 & 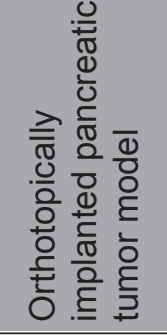 & 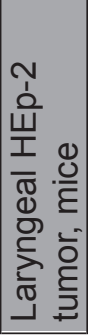 & 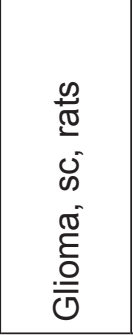 & 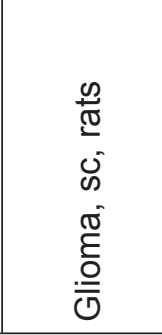 \\
\hline
\end{tabular}


cell swelling and a relative decrease in extracellular space. These data are consistent with the results of Thoeny et al. for angiogenic therapy in rhabdomyosarcomas presented above [43]. A significant linear correlation was observed between the area of ADC values $\geq 0.9 \times 10^{-3} \mathrm{~mm}^{2} / \mathrm{s}$ and the amount of necrosis in tumors pretreatment at 48 and $72 \mathrm{hr}$ after ZD6126 treatment. The authors mentioned that in cystic malignancies with high pre-treatment ADC values, DW MRI may not adequately assess early tumor response to antivascular therapy.

Dev et al. used a new type of cancer treatment that combines pulsed electric fields (PEF) with the anticancer drug bleomycin. PEF may create transient pores in the membranes which allow entry of drugs into the cells [84]. Bleomycin is a glycopeptide antibiotic that acts by induction of DNA strand breaks and/or inhibition of the incorporation of thymidine into DNA strands. DNA cleavage by bleomycin depends on the presence of oxygen and metal ions, at least in vitro. It is believed that bleomycin chelates metal ions (primarily iron) producing a pseudoenzyme that reacts with oxygen to produce superoxide and hydroxide free radicals that cleave DNA. Intratumor injection of bleomycin with PEF significantly increased water ADC 24 to $48 \mathrm{hrs}$ post-treatment of sc laryngeal tumor from $0.73 \times 10^{-3} \mathrm{~mm}^{2} / \mathrm{s}$ to $0.83 \times 10^{-3} \mathrm{~mm}^{2} / \mathrm{s}$. During this interval, spin-lattice $T_{1}$ relaxation time was unchanged while spin-spin $T_{2}$ relaxation time significantly increased in the treated group. The longer $T_{2}$ values may reflect early apoptosis and tumor death reflecting less density of the tumor cells and higher water ADC may indicate loose structural organization and necrosis after treatment.

The studies presented above allow one to conclude that in animal models, with a few exceptions, effective tumor therapy is associated with an increase in water ADC.

\section{Does Initial Level of ADC Predict Chemotherapeutic Efficiency?}

Predicting treatment response on the basis of the pre-treatment ADC value could have considerable clinical benefit as it might indicate the eventual outcome of therapy. As described above, Lemeire et al. found that mammary tumors with low initial ADC values $\left(<0.95 \times 10^{-3} \mathrm{~mm}^{2} / \mathrm{s}\right)$ responded to a single $5 \mathrm{FU}$ bolus therapy by a $30 \%$ increase in ADC at day 7 after treatment, whereas tumors with high initial ADC $\left(>1.2 \times 10^{-3} \mathrm{~mm}^{2} / \mathrm{s}\right)$ showed a $30 \%$ decrease; tumors with intermediate values showed no significant change in ADC [44]. The high and low initial ADC groups both showed a significant decrease in tumor volume after the treatment. High and low ADC values in tumors were correlated with high and low necrosis, respectively. The authors explained these results by higher absolute concentration of 5FU in tumors with low necrosis. Kamm et al. [85] previously have shown that the absolute concentration of $5 \mathrm{FU}$ and metabolites was lower in the necrotic regions of tumors compared to viable regions, an effect attributed to better vascularization of the viable regions.

Studies in human rectal carcinoma [16], [17], and colorectal hepatic metastases [86] have shown that cellular tumors with low baseline pre-treatment ADC values respond better to chemotherapy or radiation treatment than tumors that exhibit high pretreatment $A D C$ values. One possible explanation of these results is that tumors with high pre-treatment ADC values are likely to be more necrotic than those with low values. Necrotic tumors frequently are hypoxic, acidotic, and poorly perfused, leading to diminished sensitivity to chemotherapy and to radiation therapy.

However, it is still unclear if the initial ADC values can predict the clinically relevant tumor chemosensitivity in all types of tumors. Babsky et al. have found that the initial levels of water $\mathrm{ADC}$ as well as ${ }^{23} \mathrm{Na} \mathrm{SI}$ were higher in BCNU-responsive sc-implanted $9 \mathrm{~L}$

ISSN 1996-4536 • Біологічні Студії / Studia Biologica • 2009 • Том 3/№1 • С. 3-24 
gliomas compared to the BCNU non-responsive group [41]. These data suggested that a higher initial ADC level $\left(1.1-1.7 \times 10^{-3} \mathrm{~mm}^{2} / \mathrm{s}\right)$ was a promising sign for effective BCNU treatment, and in contrast, tumors with a lower initial ADC value $\left(0.6-0.9 \times 10^{-3} \mathrm{~mm}^{2} / \mathrm{s}\right)$ were most likely to be resistant to BCNU treatment. The higher pretreatment ADC levels in BCNU-responsive tumors may be related to an overall weakened condition of the cells making them vulnerable to toxic therapy. Furthermore, Seierstad et al. [46] did not find correlations between pretreatment ADC values and changes in colon adenocarcinoma HT29 xenograft volumes after chemoradiation, whereas early changes in mean ADC quantitatively correlated with treatment outcome. They conclude that „it is a prerequisite for comparing different chemotherapy regimens in animal models that initial xenografts be similar so that observed effects are therapy-induced effects and not effects originating from the initial composition of necrosis, fibrosis, and viable cells in tumors".

\section{Tumor Tissue Water ADC and ${ }^{23} \mathrm{Na}$ MRI Signal Intensity Reflects Structural Post-treatment Changes}

The increase in extracellular space following therapy can cause not only an increase in water ADC, but also an increase in total tumor tissue $\left(\mathrm{Na}_{+}^{+}\right)$, as $\left[\mathrm{Na}^{+}\right]_{e}$ is $10-15$ times higher than $\left[\mathrm{Na}^{+}\right]_{i}$. Because of its concentration, ubiquity, and short $T_{1},{ }^{23} \mathrm{Na}$ is the second most sensitive MR nucleus in tissue, with only ${ }^{1} \mathrm{H}$ being more sensitive. It has been shown that, on average, both ${ }^{23} \mathrm{Na} \mathrm{SI}$ and water ADC increased throughout the tumor after Cp (Fig. 2) or 5FU (Fig. 4) treatment of RIF-1 [40, 42]. The increase in ${ }^{23} \mathrm{Na}$ $\mathrm{SI}$ after chemotherapy could be because of an increase in concentration of total tumor tissue sodium $\left(\left[\mathrm{Na}^{+}\right]_{\uparrow}\right)$ or a change in ${ }^{23} \mathrm{Na}$ relaxation times. The authors showed that $\mathrm{Cp}$ treatment or untreated growth of RIF-1 tumors did not significantly change the $T_{1}, T_{2 s}$, and $T_{2 f}$ values or the relative contributions of $T_{2 \mathrm{~s}}$ and $T_{2 f^{\circ}}$. These results suggest that the observed increase in ${ }^{23} \mathrm{Na} \mathrm{MRI} S \mathrm{SI}$ after $\mathrm{Cp}$ treatment was due to increased $\left[\mathrm{Na}^{+}\right]_{\mathrm{t}}$ caused by $\mathrm{Cp}$ treatment. The inductively coupled plasma-mass spectroscopy (ICP-MS) data confirmed that in Cp-treated tumors, $\left[\mathrm{Na}^{+}\right]_{\mathrm{t}}$ is significantly increased three days after treatment ( $45 \pm 7 \mathrm{mM}$ control, $58 \pm 10 \mathrm{mM} \mathrm{Cp}$-treated). The value of the $\mathrm{Cp}$-induced increase in $\left[\mathrm{Na}^{+}\right]_{t}$ was comparable for both MRI (36.8\%) and ICP-MS (29.4\%) methods.

Although the extracellular space increases after therapy, $\left[\mathrm{Na}^{+}\right]_{e}$ may remain constant. $\left[\mathrm{Na}^{+}\right]_{e}$ can be maintained constantly by transport of $\mathrm{Na}^{+}$from vascular and/or interstitial space of the nearby uncompromised tissue even in hypoxic or necrotic regions. Moreover, previous ${ }^{1} \mathrm{H}$ MRI studies show that tumor perfusion is increased after therapy [87]. Thus, transport of $\mathrm{Na}^{+}$from the vascular space can maintain $\left[\mathrm{Na}^{+}\right]_{e}$, and an increase in extracellular space results in increased $\left[\mathrm{Na}^{+}\right]_{t}$ within the tumor after therapy.

There was a good correlation between ${ }^{23} \mathrm{Na} S \mathrm{SI}$ and water ADC in the $\mathrm{Cp}\left(\mathrm{R}^{2}=0.97\right)$ and 5FU $\left(R^{2}=0.99\right)$ treated tumors (Figs. 2 \& 4). One possible reason for this effect may be that $\left[\mathrm{Na}^{+}\right]_{t}$ increases with increased extracellular space because of cells lost via apoptosis and/or necrosis. Schepkin et al. [38, 39, 52] showed that an increase in ${ }^{23} \mathrm{Na}$ MRI SI occurred 7-9 days following treatment with BCNU, which correlated $\left(R^{2}=0.97\right)$ to the period of greatest chemotherapy-induced cellular necrosis based on water ADC changes and histopathology. However, in untreated growing sc $9 \mathrm{~L}$ glioma, $\left[\mathrm{Na}^{+}\right]_{\mathrm{t}}$ also increased during nine days of observation by $20 \pm 2 \mathrm{mM}$ while the mean ADC remained constant at $1.07 \pm 0.02 \times 10^{-3} \mathrm{~mm}^{2} / \mathrm{s}$ [38].

In general, necrotic tumor regions showed higher water ADC and ${ }^{23} \mathrm{Na} \mathrm{MRI} S \mathrm{SI}$ compared to viable regions in most tumors, but this is not true in some cases. In Fig. 5, for example, the histological region of sc $9 \mathrm{~L}$ glioma (b) clearly corresponds to low water ADC 

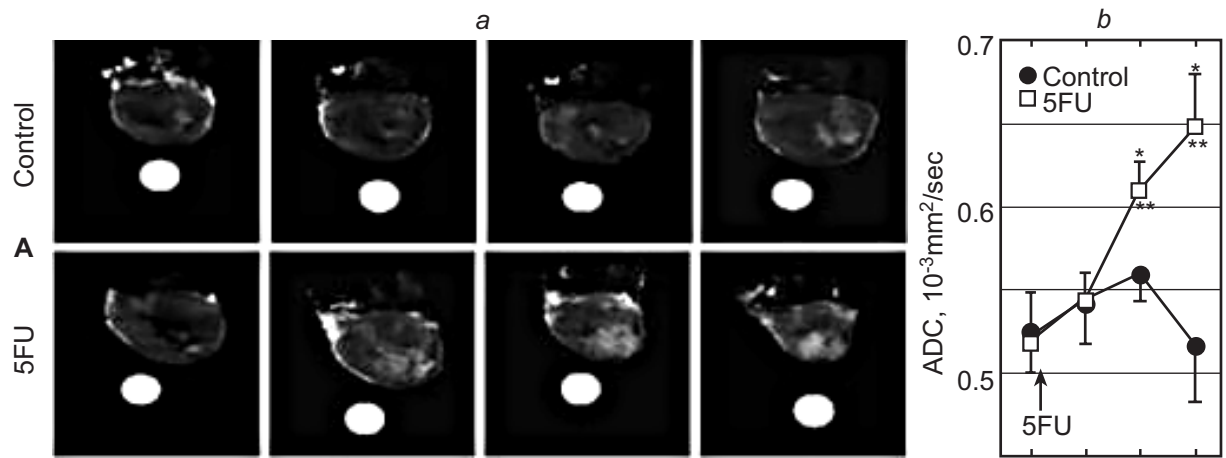

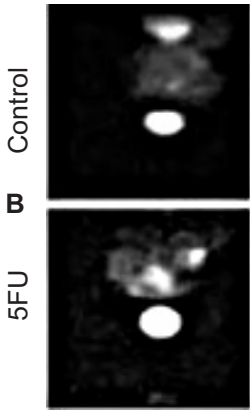

Day 0

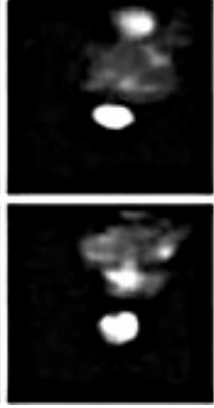

Day 1

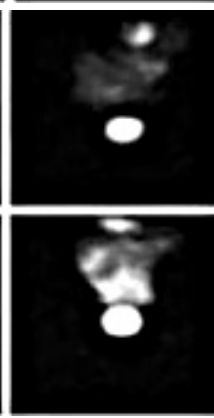

Day 2

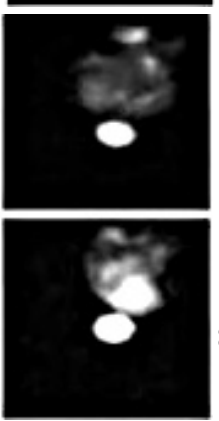

Day 3

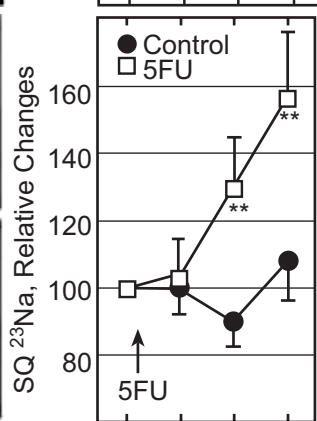

$\begin{array}{llll}0 & 1 & 2 & 3\end{array}$

Fig. 4. Correlation of changes in water apparent diffusion coefficient (ADC) (A) and single-quantum (SQ) ${ }^{23} \mathrm{Na}$ signal intensity (SI) (B) after 5-fluorouracil (5FU) therapy in subcutaneously (sc) implanted RIF-1 tumors. $a$ - on the left side the representative examples of water ADC maps and ${ }^{23} \mathrm{Na} \mathrm{MRI}$ for a control and a 5FU-treated tumor before (Day 0 ) and one, two, and three days after 5FU injection are presented; $b$ - the mean water $A D C$ and $S Q{ }^{23} \mathrm{Na}$ SI from the whole control and treated tumors. A vial filled with a $\mathrm{NaCl}$ solution was placed near the tumor as a reference. Significance: $p \leq 0.05\left({ }^{*}-\mathrm{vs}\right.$. before treatment), $\mathrm{p} \leq 0.01$ ( ${ }^{* *}-$ Control vs. 5FU-treated). Data are presented as mean \pm SEM

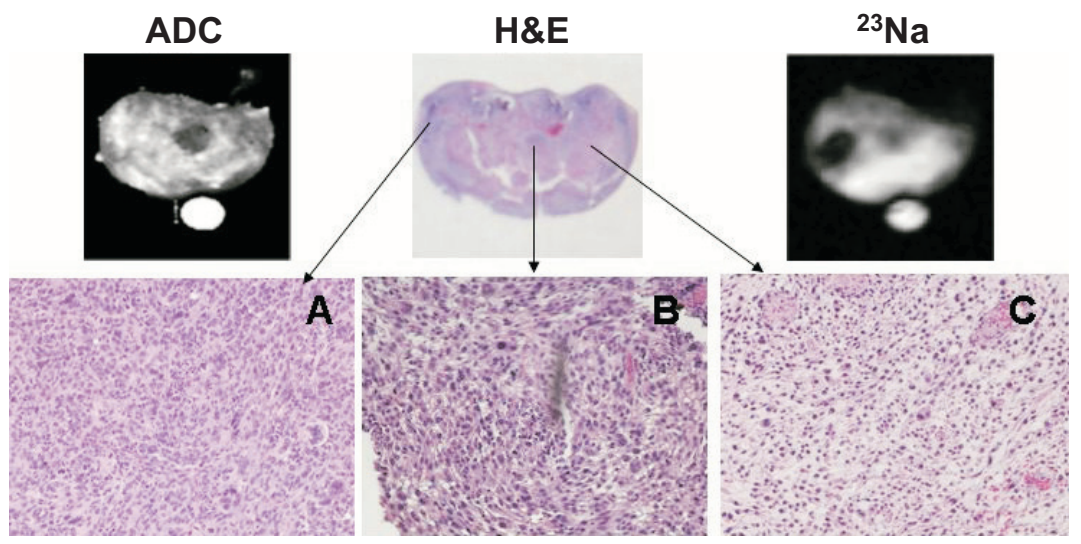

Fig. 5. Stained with hematoxylin and eosin (H\&E) histological slices $(A-C)$, water apparent diffusion coefficient (ADC), and ${ }^{23} \mathrm{Na}$ images of subcutaneous $9 \mathrm{~L}$ glioma. Histological slice from the middle part of the tumor is presented. Arrows point the regions identified as „viable” (A, B) and „necrotic” (C). These regions are presented as high-resolution (original magnification, $\times 200$ ) histological images 
and ${ }^{23} \mathrm{Na} \mathrm{MRI} \mathrm{SI.} \mathrm{However,} \mathrm{another} \mathrm{region} \mathrm{with} \mathrm{high} \mathrm{cellular} \mathrm{density} \mathrm{on} \mathrm{the} \mathrm{left} \mathrm{side} \mathrm{of} \mathrm{the}$ tumor (a) corresponds to an area with high water ADC and low ${ }^{23} \mathrm{Na} \mathrm{MRI} \mathrm{SI.} \mathrm{On} \mathrm{the} \mathrm{other}$ hand, the region with low cellular density on the right side of the tumor (c) corresponds to high ${ }^{23} \mathrm{Na} \mathrm{MRI} \mathrm{SI} \mathrm{and} \mathrm{intermediate} \mathrm{water} \mathrm{ADC.} \mathrm{This} \mathrm{discrepancy} \mathrm{may} \mathrm{reflect} \mathrm{the} \mathrm{fact} \mathrm{that}$ $\left[\mathrm{Na}^{+}\right]$and water diffusion in tissue are influenced by different factors. Tissue $\left[\mathrm{Na}^{+}\right]$depends mainly on relative ECS and $\left[\mathrm{Na}^{+}\right]_{i}$ because $\left[\mathrm{Na}^{+}\right]_{e}$ is largely constant, while water ADC is affected not only by the size of different tissue compartments but also by the biophysical environments in these compartments. For example, a tumor region that is rich in collagen may have low water ADC but high tissue $\left[\mathrm{Na}^{+}\right]$. Thus, ${ }^{23} \mathrm{Na} \mathrm{MRI}$ may provide additional information about the effects of therapy and untreated growth on tumor microenvironment compared to that which is available from water ADC measurements alone.

\title{
CONCLUSION
}

DWI is a powerful, non-invasive MRI tool that provides unique information related to structural, cellular, apoptotic, and necrotic changes in tumor tissue. The technique can be used widely for tumor detection and characterization and for monitoring of response to treatment. Effective tumor therapy is usually associated with an increase in ADC values, although exceptions may occur. Water ADC appears to have the ability to predict treatment response to chemotherapy. However, there are several challenges to wider use of DWI in cancer patients. These include a lack of accepted standards for data acquisition and analysis, variability of ADC changes depending on tumor cell type and location, motion effects on body tumor ADC measurements, incomplete theoretical understanding of DWI in ECS and ICS, and poorly understood multiexponential decay components which affect the calculated ADC values. Thus, DWI protocols and analyses need to be adapted to individual tumor types, anatomic locations and therapies. We also need a better understanding of how tumor water ADC measurements can be combined with results of other diagnostic modalities, such as ${ }^{23} \mathrm{Na} \mathrm{MRI},{ }^{31} \mathrm{P}$ MR spectroscopy, positron emission tomography, destructive chemical analysis, and histology, to improve our assessment of prognosis and better monitoring of therapeutic efficiency.

\section{Acknowledgements}

The authors thank Samuel G. Jennings for valuable comments and assistance in the preparation of the manuscript.

\section{ВИКОРИСТАННЯ КОЕФІЦІЄНТА ДИФУЗІЇ ВОДИ ДЛЯ ОЦІНКИ ЕФЕКТИВНОСТІ ТЕРАПІЇ ЕКСПЕРИМЕНТАЛЬНИХ ПУХЛИН У ТВАРИН}

\author{
А. М. Бабський ${ }^{1,2}$, Ш. Джи ${ }^{1,3}$, Н. Банзал ${ }^{1}$ \\ ${ }^{1}$ Відділ радіології Індіанського університету, Індіанаполіс, Індіана 46202, США \\ ${ }^{2}$ Львівський національний університет імені Івана Франка, \\ вул. Грушевського, 4, Львів 79005, Україна \\ ${ }^{3}$ Центральний госпіталь Південно-східного університету, Нанджін 210009, \\ Народна Республіка Китай \\ e-mail: ababsky@iupui.edu
}

У статті підсумовано власні результати авторів і літературні дані, присвячені використанню показників дифузії води, що вимірюються методом дифузійно-граді- 
єнтних зображень ядерно-магнітного резонансу, для оцінки структурних та внутрішньоклітинниих змін, пов'язаних із апоптозними чи некротичними трансформаціями у ракових пухлинах. Обговорюється можливість використання змін коефіцієнта дифузії води для ранньої діагностики, оцінки ефективності протипухлинної терапії та з'ясування механізмів канцерогенезу на прикладах експериментальних пухлин, прищеплених тваринам.

Ключові слова: пухлина, хіміотерапія, коефіцієнт дифузії води, Натрій, ядерно-магнітний резонанс.

\title{
ИСПОЛЬЗОВАНИЕ КОЭФФИЦИЕНТА ДИФФУЗИИ ВОДЫ ДЛЯ ОЦЕНКИ ЭФФЕКТИВНОСТИ ТЕРАПИИ ЭКСПЕРИМЕНТАЛЬНЫХ ОПУХОЛЕЙ У животныХ
}

\author{
А. М. Бабский ${ }^{1,2}$, Ш. Джи ${ }^{1,3}$, Н. Банзал ${ }^{1}$ \\ ${ }^{1}$ Отдел радиологии Индианского университета, Индианаполис, Индиана 46202, США \\ ${ }^{2}$ Львовский национальный университет имени Ивана Франко, \\ ул. Грушевского, 4, Львов 79005, Украина \\ ${ }^{3}$ Центральный госпиталь Юго-восточного университета, \\ Нанджин 210009, Народная Республика Китай
}

В статье подытожены результаты авторов и литературные данные посвященные использованию показателей диффузии воды, которые измеряются с использованием дифффузионно-градиентных изображений ядерно-магнитного резонанса, для оценки структурных и внутриклеточных изменений, связанных с апоптозными или некротическими трансформациями в раковых опухолях. Обсуждается возможность использования изменений коэффициента диффузии воды для ранней диагностики, оценки эффрективности противоопухолевой терапии и выяснения механизмов канцерогененза на примерах экспериментальных опухолей у животных.

1. Walker M.D., Alexander E., Jr., Hunt W.E. et al. Evaluation of BCNU and/or radiotherapy in the treatment of anaplastic gliomas. A cooperative clinical trial. J. Neurosurg, 1978; 49: 333-343.

2. Chisholm R.A., Stenning S., Hawkins T.D. The accuracy of volumetric measurement of highgrade gliomas. Clin. Radiol, 1989; 40: 17-21.

3. James K., Eisenhauer E., Christian M. et al. Measuring response in solid tumors: unidimensional versus bidimensional measurement. J. Natl. Cancer Inst, 1999; 91: 523-528.

4. MacDonald D.R., Cascino T.L., Schold S.C., Jr., Cairncross J.G. Response criteria for phase II studies of supratentorial malignant glioma. J. Clin. Oncol, 1990; 8: 1277-1280.

5. Belhocine T., Steinmetz N., Green A., Rigo P. In vivo imaging of chemotherapy-induced apoptosis in human cancers. Ann. N. Y. Acad. Sci, 2003; 1010: 525-529.

6. Blankenberg F., Mari C., Strauss H.W. Imaging cell death in vivo. Q. J. Nucl. Med, 2003; 47: 337-348.

7. Nelson S.J., Cha S. Imaging glioblastoma multiforme. Cancer J, 2003; 9: 134-145.

8. Ross B.D., Chenevert T.L., Garwood M. et al. Evaluation of (E)-2'-deoxy-2'-(fluoromethylene) cytidine on the 9L rat brain tumor model using MRI. NMR Biomed, 2003; 16: 67-76.

9. Spence A.M., Mankoff D.A., Muzi M. Positron emission tomography imaging of brain tumors. Neuroimaging Clin. N. Am, 2003; 13: 717-739.

10. Van de Wiele C,. Lahorte C., Oyen $W$. et al. Nuclear medicine imaging to predict response to radiotherapy: a review. Int. J. Radiat. Oncol. Biol. Phys, 2003; 55: 5-15.

ISSN 1996-4536 • Біологічні Студії / Studia Biologica • 2009 • Том 3/№1 • С. 3-24 
11. Ross B., Chenvert T., Kim B., Ben-Yoseph O. Magnetic resonanse imaging and spectroscopy: application to experimental neurooncology. Quart. Magn. Resn. Biol. Med, 1994; 1: 89-106.

12. Thoeny H.C., De Keyzer F. Extracranial applications of diffusion-weighted magnetic resonance imaging. Eur. Radiol, 2007; 17: 1385-1393.

13. Geschwind J.F., Artemov D., Abraham S. et al. Chemoembolization of liver tumor in a rabbit model: assessment of tumor cell death with diffusion-weighted MR imaging and histologic analysis. J. Vasc. Interv. Radiol, 2000;11: 1245-1255.

14. Stegman L.D., Rehemtulla A., Hamstra D.A. et al. Diffusion MRI detects early events in the response of a glioma model to the yeast cytosine deaminase gene therapy strategy. Gene. Ther, 2000; 7: 1005-1010.

15. Chenevert T.L., Stegman L.D., Taylor J.M. et al. Diffusion magnetic resonance imaging: an early surrogate marker of therapeutic efficacy in brain tumors. J. Natl. Cancer Inst, 2000; 92: 2029-2036.

16. DeVries A.F., Kremser C., Hein P.A. et al. Tumor microcirculation and diffusion predict therapy outcome for primary rectal carcinoma. Int. J. Radiat. Oncol. Biol. Phys, 2003; 56: 958-965.

17. Dzik-Jurasz A., Domenig C., George M. et al. Diffusion MRI for prediction of response of rectal cancer to chemoradiation. Lancet, 2002; 360: 307-308.

18. Galons J.P., Altbach M.I., Paine-Murrieta G.D. et al. Early increases in breast tumor xenograft water mobility in response to paclitaxel therapy detected by non-invasive diffusion magnetic resonance imaging. Neoplasia, 1999; 1: 113-117.

19. Thoeny H.C., De Keyzer F., Chen F. et al. Diffusion-weighted MR imaging in monitoring the effect of a vascular targeting agent on rhabdomyosarcoma in rats. Radiology, 2005; 234: 756-764.

20. Chenevert T.L., McKeever P.E., Ross B.D. Monitoring early response of experimental brain tumors to therapy using diffusion magnetic resonance imaging. Clin. Cancer Res, 1997; 3 : 1457-1466.

21. Chinnaiyan A.M., Prasad U., Shankar S. et al. Combined effect of tumor necrosis factor-related apoptosis-inducing ligand and ionizing radiation in breast cancer therapy. Proc. Natl. Acad. Sci. USA, 2000; 97: 1754-1759.

22. Hakumaki J.M., Poptani H., Puumalainen A.M. et al. Quantitative ${ }^{1} \mathrm{H}$ nuclear magnetic resonance diffusion spectroscopy of BT4C rat glioma during thymidine kinase-mediated gene therapy in vivo: identification of apoptotic response. Cancer Res, 1998; 58: 3791-3799.

23. Poptani H., Puumalainen A.M., Grohn O.H. et al. Monitoring thymidine kinase and ganciclovir-induced changes in rat malignant glioma in vivo by nuclear magnetic resonance imaging. Cancer Gene. Ther, 1998; 5: 101-109.

24. Zhao M., Pipe J.G., Bonnett J., Evelhoch J.L. Early detection of treatment response by diffusionweighted ${ }^{1} \mathrm{H}-\mathrm{NMR}$ spectroscopy in a murine tumour in vivo. Br. J. Cancer, 1996; 73: 61-64.

25. Hein P.A., Kremser C., Judmaier W. et al. Diffusion-weighted magnetic resonance imaging for monitoring diffusion changes in rectal carcinoma during combined, preoperative chemoradiation: preliminary results of a prospective study. Eur. J. Radiol, 2003; 45: 214-222.

26. Kremser C., Judmaier W., Hein P. et al. Preliminary results on the influence of chemoradiation on apparent diffusion coefficients of primary rectal carcinoma measured by magnetic resonance imaging. Strahlenther. Onkol, 2003; 179: 641-649.

27. Mardor Y., Pfeffer R., Spiegelmann R. et al. Early detection of response to radiation therapy in patients with brain malignancies using conventional and high $b$-value diffusion-weighted magnetic resonance imaging. J. Clin. Oncol, 2003; 21: 1094-1100.

28. Ross B.D., Moffat B.A., Lawrence T.S. et al. Evaluation of cancer therapy using diffusion magnetic resonance imaging. Mol. Cancer Ther, 2003; 2: 581-587.

29. Koh D.M., Collins D.J. Diffusion-weighted MRI in the body: applications and challenges in oncology. AJR Am. J. Roentgenol, 2007; 188: 1622-1635.

30. Sykova E., Svoboda J., Polak J., Chvatal A. Extracellular volume fraction and diffusion characteristics during progressive ischemia and terminal anoxia in the spinal cord of the rat. J. Cereb. Blood. Flow. Metab, 1994; 14: 301-311. 
31. Sugahara T., Korogi Y., Kochi M. et al. Usefulness of diffusion-weighted MRI with echo-planar technique in the evaluation of cellularity in gliomas. J. Magn. Reson. Imaging, 1999; 9: 53-60.

32. Lyng H., Haraldseth O., Rofstad E.K. Measurement of cell density and necrotic fraction in human melanoma xenografts by diffusion weighted magnetic resonance imaging. Magn. Reson. Med, 2000; 43: 828-836.

33. Guo A.C., Cummings T.J., Dash R.C., Provenzale J.M. Lymphomas and high-grade astrocytomas: comparison of water diffusibility and histologic characteristics. Radiology, 2002; 224: 177-183.

34. Szafer A., Zhong J., Gore J.C. Theoretical model for water diffusion in tissues. Magn. Reson. Med, 1995; 33: 697-712.

35. Moffat B.A., Chenevert T.L., Lawrence T.S. et al. Functional diffusion map: a noninvasive MRI biomarker for early stratification of clinical brain tumor response. Proc. Natl. Acad. Sci. USA, 2005; 102: 5524-5529.

36. Babsky A.M., Topper S., Zhang H. et al. Evaluation of extra- and intracellular apparent diffusion coefficient of sodium in rat skeletal muscle: effects of prolonged ischemia. Magn. Reson. Med, 2008; 59: 485-491.

37. Duong T.Q., Ackerman J.J., Ying H.S., Neil J.J. Evaluation of extra- and intracellular apparent diffusion in normal and globally ischemic rat brain via 19F NMR. Magn. Reson. Med, 1998; 40: 1-13.

38. Schepkin V., Chenevert T., Kuszpit K. et al. Sodium and proton diffusion MRI as biomarkers for early therapeutic response in subcutaneous tumors. Magn. Reson. Imaging, 2006; 24: 273-278.

39. Schepkin V.D., Lee K.C., Kuszpit K. et al. Proton and sodium MRI assessment of emerging tumor chemotherapeutic resistance. NMR Biomed, 2006; 19: 1035-1042.

40. Babsky A., Hekmatyar S., Zhang H. et al. Application of ${ }^{23} \mathrm{Na}$ MRI to monitor chemotherapeutic response in RIF-1 tumors. Neoplasia, 2005; 7: 658-666.

41. Babsky A., Hekmatyar S., Zhang H. et al. Predicting and monitoring response to chemotherapy by 1,3-bis(2-chloroethyl)-1-nitrosourea in subcutaneously implanted 9L glioma using the apparent diffusion coefficient of water and ${ }^{23} \mathrm{Na}$ MRI. J. Magn. Reson. Imaging, 2006; 24: 132-139.

42. Babsky A.M., Zhang H., Hekmatyar S.K. et al. Monitoring chemotherapeutic response in RIF1 tumors by single-quantum and triple-quantum-filtered ${ }^{23} \mathrm{Na} \mathrm{MRI},{ }^{1} \mathrm{H}$ diffusion-weighted MRI and PET imaging. Magn. Reson. Imaging, 2007; 25: 1015-1023.

43. Thoeny H.C., De Keyzer F., Chen F. et al. Diffusion-weighted magnetic resonance imaging allows noninvasive in vivo monitoring of the effects of combretastatin a-4 phosphate after repeated administration. Neoplasia, 2005; 7: 779-787.

44. Lemaire L., Howe F.A., Rodrigues L.M., Griffiths J.R. Assessment of induced rat mammary tumour response to chemotherapy using the apparent diffusion coefficient of tissue water as determined by diffusion-weighted ${ }^{1} \mathrm{H}-\mathrm{NMR}$ spectroscopy in vivo. MAGMA, 1999; 8: 20-26.

45. Zhao M., Pipe J.G., Bonnett J., Evelhoch J.L. Early detection of treatment response by diffusion-weighted ${ }^{1} \mathrm{H}-\mathrm{NMR}$ spectroscopy in a murine tumour in vivo. Br. J. Cancer, 1996; 73 : 61-64.

46. Seierstad T., Folkvord S., Roe K. et al. Early changes in apparent diffusion coefficient predict the quantitative antitumoral activity of capecitabine, oxaliplatin, and irradiation in HT29 xenografts in athymic nude mice. Neoplasia, 2007; 9: 392-400.

47. Galons J.P., Altbach M.I., Paine-Murrieta G.D. et al. Early increases in breast tumor xenograft water mobility in response to paclitaxel therapy detected by non-invasive diffusion magnetic resonance imaging. Neoplasia, 1999; 1: 113-117.

48. Morse D.L., Galons J.P., Payne C.M. et al. MRI-measured water mobility increases in response to chemotherapy via multiple cell-death mechanisms. NMR Biomed, 2007; 20: 602-614.

49. Thoeny H.C., De Keyzer F., Vandecaveye V. et al. Effect of vascular targeting agent in rat tumor model: dynamic contrast-enhanced versus diffusion-weighted MR imaging. Radiology, 2005; 237: 492-499.

ISSN 1996-4536 • Біологічні Студії / Studia Biologica • 2009 • Том 3/№1 • С. 3-24 
50. Seierstad T., Roe K., Olsen D.R. Noninvasive monitoring of radiation-induced treatment response using proton magnetic resonance spectroscopy and diffusion-weighted magnetic resonance imaging in a colorectal tumor model. Radiother. Oncol, 2007; 85: 187-194.

51. Roth Y., Tichler T., Kostenich G. et al. High-b-value diffusion-weighted MR imaging for pretreatment prediction and early monitoring of tumor response to therapy in mice. Radiology, 2004; 232: 685-692.

52. Schepkin V.D., Ross B.D., Chenevert T.L. et al. Sodium magnetic resonance imaging of chemotherapeutic response in a rat glioma. Magn. Reson. Med, 2005; 53: 85-92.

53. Jordan B.F., Runquist M., Raghunand N. et al. Dynamic contrast-enhanced and diffusion MRI show rapid and dramatic changes in tumor microenvironment in response to inhibition of HIF1alpha using PX-478. Neoplasia, 2005; 7: 475-4854.

54 Le Bihan D., Delannoy J., Levin R.L. Temperature mapping with MR imaging of molecular diffusion: application to hyperthermia. Radiology, 1989; 171: 853-857.

55. Morvan D., Leroy-Willig A. Simultaneous measurements of diffusion and transverse relaxation in exercising skeletal muscle. Magn. Reson. Imaging, 1995; 13: 943-948.

56. Braunschweiger P.G. Effect of cyclophosphamide on the pathophysiology of RIF-1 solid tumors. Cancer Res, 1988; 48: 4206-4210.

57. Padhani A., Liu G., Koh D.M. et al. Diffusion weighted magnetic resonance imaging as a cancer biomarker: consensus and recommendations. Neoplasia, 2009; 11: 102-125.

58. Boucher E., Corbinais S., Brissot P. et al. Treatment of hepatocellular carcinoma (HCC) with systemic chemotherapy combining epirubicin, cisplatinum and infusional 5-fluorouracil (ECF regimen). Cancer Chemother. Pharmacol, 2002; 50: 305-308.

59. Iwamiya T., Sawada S., Ohta Y. Repeated arterial infusion chemotherapy for inoperable hepatocellular carcinoma using an implantable drug delivery system. Cancer Chemother. Pharmacol, 1994; 33 Suppl: S134-138.

60. Yanase K., Yoshiji H., Ikenaka Y. et al. Synergistic inhibition of hepatocellular carcinoma growth and hepatocarcinogenesis by combination of 5 -fluorouracil and angiotensin-converting enzyme inhibitor via anti-angiogenic activities. Oncol. Rep, 2007; 17: 441-446.

61. Helmer K.G., Meiler M.R., Sotak C.H., Petruccelli J.D. Comparison of the return-to-the-origin probability and the apparent diffusion coefficient of water as indicators of necrosis in RIF-1 tumors. Magn. Reson. Med, 2003; 49: 468-478.

62. Chenevert T.L., Stegman L.D., Taylor J.M. et al. Diffusion magnetic resonance imaging: an early surrogate marker of therapeutic efficacy in brain tumors. J. Natl. Cancer Inst, 2000; 92: 2029-2036.

63. Tozer G.M., Kanthou C., Parkins C.S., Hill S.A. The biology of the combretastatins as tumour vascular targeting agents. Int. J. Exp. Pathol, 2002; 83: 21-38.

64. Welsh S., Williams R., Kirkpatrick L. et al. Antitumor activity and pharmacodynamic properties of PX-478, an inhibitor of hypoxia-inducible factor-1alpha. Mol. Cancer Ther, 2004; 3: 233-244.

65. Chinnaiyan A.M., Prasad U., Shankar S. et al. Combined effect of tumor necrosis factor-related apoptosis-inducing ligand and ionizing radiation in breast cancer therapy. Proc. Natl. Acad. Sci. USA, 2000; 97: 1754-1759.

66. Lyseng-Williamson K.A., Fenton C. Docetaxel: a review of its use in metastatic breast cancer. Drugs, 2005; 65: 2513-2531.

67. Chenevert T., McKeever P., Ross B. Monitoring early response of experimental brain tumors to therapy using diffusion magnetic resonance imaging. Clin. Cancer. Res, 1997; 3: 1457-1466.

68. Ross B., Chenevert T., Rehemtulla A. Magnetic resonance imaging in cancer research. Eur. J. Cancer, 2002; 38: 2147-2156.

69. Ross B., Moffat B., Lawrence T. et al. Evaluation of cancer therapy using diffusion magnetic resonance imaging. Mol. Cancer Ther, 2003; 2: 581-587.

70. Ross B.D., Zhao Y.J., Neal E.R. et al. Contributions of cell kill and posttreatment tumor growth rates to the repopulation of intracerebral $9 \mathrm{~L}$ tumors after chemotherapy: an MRI study. Proc. Natl. Acad. Sci. USA, 1998; 95: 7012-7017. 
71. Winter P.M., Poptani H., Bansal N. Effects of chemotherapy by 1,3-bis(2-chloroethyl)-1-nitrosourea on single-quantum- and triple-quantum-filtered ${ }^{23} \mathrm{Na}$ and ${ }^{31} \mathrm{P}$ nuclear magnetic resonance of the subcutaneously implanted 9L glioma. Cancer Res, 2001; 61: 2002-2007.

72. Steen R.G., Tamargo R.J., McGovern K.A. et al. In vivo ${ }^{31} \mathrm{P}$ nuclear magnetic resonance spectroscopy of subcutaneous $9 \mathrm{~L}$ gliosarcoma: effects of tumor growth and treatment with 1,3-bis(2-chloroethyl)-1-nitrosourea on tumor bioenergetics and histology. Cancer Res, 1988; 48: 676-681.

73. Steen R.G. Response of solid tumors to chemotherapy monitored by in vivo 31P nuclear magnetic resonance spectroscopy: a review. Cancer Res, 1989; 49: 4075-4085.

74. Ameer G.A., Crumpler E.T., Langer R. Cell-killing potential of a water-soluble radical initiator. Int. J. Cancer, 2001; 93: 875-879.

75. Dzik-Jurasz A., Domenig C., George M. et al. Diffusion MRI for prediction of response of rectal cancer to chemoradiation. Lancet, 2002; 360: 307-308.

76. Mardor Y., Roth Y., Lidar Z. et al. Monitoring response to convection-enhanced taxol delivery in brain tumor patients using diffusion-weighted magnetic resonance imaging. Cancer Res, 2001; 61: 4971-4973.

77. Yuan Y.H., Xiao E.H., Liu J.B. et al. Characteristics and pathological mechanism on magnetic resonance diffusion-weighted imaging after chemoembolization in rabbit liver VX-2 tumor model. World J. Gastroenterol, 2007; 13: 5699-5706.

78. Yuan Y.H., Xiao E.H., Liu J.B. et al. Gene expression and MR diffusion-weighted imaging after chemoembolization in rabbit liver VX-2 tumor model. World J. Gastroenterol, 2008; 14: 5557-5563.

79. Momparler R.L., Karon M., Siegel S.E., Avila F. Effect of adriamycin on DNA, RNA, and protein synthesis in cell-free systems and intact cells. Cancer Res, 1976; 36: 2891-2895.

80. Kim H., Morgan D.E., Buchsbaum D.J. et al. Early therapy evaluation of combined anti-death receptor 5 antibody and gemcitabine in orthotopic pancreatic tumor xenografts by diffusionweighted magnetic resonance imaging. Cancer Res, 2008; 68: 8369-8376.

81. Jennings D., Hatton B.N., Guo J. et al. Early response of prostate carcinoma xenografts to docetaxel chemotherapy monitored with diffusion MRI. Neoplasia, 2002; 4: 255-262.

82. Vogel-Claussen J., Gimi B., Artemov D., Bhujwalla Z.M. Diffusion-weighted and macromolecular contrast enhanced MRI of tumor response to antivascular therapy with ZD6126. Cancer Biol. Ther, 2007; 6: 1469-1475.

83. Micheletti G., Poli M., Borsotti P. et al. Vascular-targeting activity of ZD6126, a novel tubulinbinding agent. Cancer Res, 2003; 63: 1534-1537.

84. Dev S.B., Caban J.B., Nanda G.S. et al. Magnetic resonance studies of laryngeal tumors implanted in nude mice: effect of treatment with bleomycin and electroporation. Magn. Reson. Imaging, 2002; 20: 389-394.

85. Kamm Y.J., Heerschap A., Rosenbusch G. et al. 5-Fluorouracil metabolite patterns in viable and necrotic tumor areas of murine colon carcinoma determined by $19 \mathrm{~F}$ NMR spectroscopy. Magn. Reson. Med, 1996; 36: 445-450.

86. Koh D.M., Scurr E., Collins D. et al. Predicting response of colorectal hepatic metastasis: value of pretreatment apparent diffusion coefficients. AJR Am. J. Roentgenol, 2007; 188: 1001-1008.

87. Poptani H., Bansal N,. Graham R.A. et al. Detecting early response to cyclophosphamide treatment of RIF-1 tumors using selective multiple quantum spectroscopy (SeIMQC) and dynamic contrast enhanced imaging. NMR Biomed, 2003; 16: 102-111.

Одержано: 19.01.2009 